\title{
HUBUNGAN PERAN ORANG TUA DENGAN PERILAKU KONSUMSI MINUMAN ALKOHOL PADA REMAJA LAKI-LAKI
}

\author{
Solina $^{1}$, Triana Arisdiani ${ }^{1}$, Yuni Puji Widyastuti ${ }^{1}$ \\ ${ }^{1}$ Program Studi Ilmu Keperawatan, STIKES Kendal \\ arisdiani86@gmail.com
}

\begin{abstract}
ABSTRAK
Perilaku konsumsi minuman alkohol merupakan permasalahan yang cukup berkembang dan meningkat dari tahun ketahun.Perilaku konsumsi alkohol di Desa Gringsing cukup sering ditemukan.Orang tua merupakan lingkungan pertama yang berhubungan dengan remaja.Peran orang tua diharapkan dapat mencegah perilaku konsumsi minuman alkohol pada remaja laki-laki.Tujuan penelitian ini untuk mengetahui hubungan peran orang tua dengan perilaku konsumsi minuman alkohol pada remaja laki-laki di Desa Gringsing Kecamatan Gringsing Kabupaten Batang. Penelitian ini menggunakan desain kuantitatif, Metode penelitian deskriptif korelatif dengan pendekatan cross sectional. Sampel dalam penelitian ini berjumlah 150 responden dengan teknik pengambilan purposive sampling.Alat ukur berupa kuesioner sebanyak 20 pertanyaan untuk variabel peran orang tua dan 10 pertanyaan perilaku konsumsi minuman beralkohol.Analisa data menggunakan univariat dan bivariat. Hasil penelitian menunjukkan bahwa sebagian besar peran orang tua cukup sebanyak sebanyak 95 responden $(63,3 \%)$. Perilaku konsumsi minuman alkohol sebagian besar peminum berbahaya dan tidak ada hubungan peran orang tua dengan perilaku konsumsi minuman alkohol pada remaja lakilaki.Diharapkanorang tua harus memotivasi remaja untuk tidak mengkonsumsi minum-minuman keras, memberikan pengetahuan tentang bahaya minuman keras kepada remaja bertindak tegas untuk melarang anaknya minum-minuman keras dan tidak memberikan fasilitas kepada anak untuk minumminuman keras.
\end{abstract}

Kata kunci:Peran orangtua, perilaku, minuman beralkohol

\section{THE RELATION BETWEEN THE PARENTS' ROLE AND THE MALE ADOLESCENTS' ALCOHOL CONSUMPTION BEHAVIOR}

\begin{abstract}
Alcohol Consumption behavior is problematic and increasing from year to year. Such behavior is frequently found in Gringsing Village. It is parents who are considered as the first environment in connection with adolescents. Parents are expected to play an important role in preventing the male adolescents' alcohol consumption behavior. The research aims to see the relation between the parents' role and the male adolescents' alcohol consumption behavior in Gringsing Village, Gringsing Subdistrict, Batang Regency. The research design was quantitative and used a descriptive correlational method with cross-sectional approach. 150 respondents participated in this research and were taken by a purposive sampling technique. The instrument of this research was closed questionnaire, which consist of 20 questions dealing with the variable of the parents' role and 10 questions about alcohol consumption behavior. The result of the research show that 95 respondents (63.3\%) agreed with the parents' important role and it is the male adolescents who mostly consumed alcohol and the result also shows that there was no correlation between the parents' role and alcohol consumption behavior. Parents are expected to be able to motivate the male adolescents not to consume alcohol, inform them the danger of alcohol consumption, strictlyforbid them from drinking alcohol, and not to facilitate their alcohol consumption.
\end{abstract}

Keywords: parents' roles, behavior, alcohol drink 


\section{PENDAHULUAN}

Peran orangtua menggambarkan serangkaian pola perilaku yang didasari oleh beliefs (keyakinan dan sikap) orang tua, sehingga membawa pada perubahan sikap diri sendiri dan orang lain (Friedman, 2010). Peran orang tua merupakan salah satu aspek yang penting agar remaja dapat mengatasi masalah atau stres (Santock, 2013).Orang tua harus memberikan pengertian melalui cara-cara yang dewasa, memberikan dukungan atau motivasi yang positif untuk menunjang keberhasilan akhlak remaja (Soekanto, 2014).

Masa remaja merupakan masa transisi dari kanak-kanak menuju masa dewasa yang dimulai dari usia belasan tahun sampai dua puluhan tahun (Hurlock, 2010). United Nations Fund for Population Activities (UNFPA) dan Perserikatan Bangsa Bangsa (PBB)mengembangkan kelompok remaja adalah kelompok dewasa muda (young people) dengan usia 10-24 tahun (Kiswoyo, 2013). Batasan umur remaja menurut Survei Demografi dan Kesehatan di Indonesia sendiri menggunakan batasan usia 15-24 tahun dan belum menikah (Kemenkes. RI, 2012).

Periode transisi yang dialami pada masa remaja terjadi perubahan intelektual dan hasrat pencarian identitas yang kuat sebagai orang dewasa, namun emosional remaja cenderung labil (Hurlock, 2010).Ketidakmampuan remaja untuk mengendalikan emosionalnya seringkali memunculkan perilaku menyimpang (Stanhope\& Lancaster, 2014). Perilaku menyimpang remaja pada norma-norma umum, adat istiadat, hukum formal diantaranya adalah perilaku konsumsi minuman alkohol yang sudah menjadi masalah sosial yang sampai saat ini belum dapat diatasi secara tuntas (Kartono, 2011)

Perilaku konsumsi minuman alkohol saat ini merupakan permasalahan yang cukup berkembang didunia remaja dan menunjukan kecenderungan yang meningkat dari tahun ke tahun, akibatnya mereka melakukan bentuk kenakalan-kenakalan, perkelahian, geng-geng remaja, perbuatan asusila dan maraknya premanisme pada kalangan remaja (Hutagalung, 2008).Minuman alkohol adalah segala jenis minuman yang memabukan, sehingga dengan meminumnya menjadi hilang kesadaranya, yang termasuk minuman alkohol seperti arak, wine, whisky, brandy, sampagne, malagadan lain lain (Zulvikar, 2008).
World Health Organization (2014) menyebutkan di seluruh dunia $61,7 \%$ dari penduduk berusia 15 tahun atau lebih tua (15+) pernah minum alkohol dalam 12 bulan terakhir, bahkan sekitar $16,0 \%$ adalah peminum berat. Republik Moldova, Belarus, Lithuania, Rusia dan Republik Ceko tercatat sebagai lima negara dengan tingkat konsumsi alkohol per kapita tertinggi di dunia pada 2015. Rata-rata penduduk di negara ini, untuk mereka yang telah berumur lebih dari 15 tahun mengkonsumsi 15,8 liter alkohol (disetarakan dengan alkohol murni per tahun). Penduduk Republik Maldova tercatat paling tinggi dengan jumlah konsumsi 17,4 liter (Kumara, 2016).

Pemakaian alkohol di Indonesia juga menunjukkan potensi peningkatan penggunaan alkohol yang cukup besar. Berdasarkan data Riset Kesehatan Dasar (Riskesdas) tahun 2007, prevalensi konsumsi alkohol di Indonesia dari 258.366 sampel rumah tangga pada 1 tahun terakhir adalah $8,8 \%$ laki-laki dan $0,7 \%$ perempuan. Prevalensi peminum alkohol mulai tinggi pada umur antara 15-24 tahun yaitu sebesar 5,5\% meningkat menjadi $6,7 \%$ pada umur 25-34 tahun (Kemenkes. RI, 2007).

Data Survei Demografi dan Kesehatan Indonesia (SDKI) tahun 2012 tentang kesehatan remaja menyebutkan bahwa pria lebih berisiko terlibat dalam perilaku konsumsi alkohol dibandingkan dengan wanita. Hasil survei menunjukkan $4 \%$ pada wanita dan $40 \%$ pada pria. Data menunjukkan klasifikasi pengonsumsi minuman beralkohol 30,2\% remaja putra usia 15-19 tahun dan 52,9\% remaja putra usia 20-24 tahun sudah minum minuman beralkohol (Kemenkes. RI, 2012). Perilaku konsumsi minuman alkohol di Jawa Tengah diperkirakan sekitar $25 \%$ pada remaja, dengan golongan umur 15-24 tahun sebesar 4,5\%, golongan umur 25-34 tahun sebesar $4,2 \%$, data juga menunjukkan terbanyak dari golongan setingkat pelajar SLTP/SLTA yaitu sebesar 5,2\% (Dinkes Jateng, 2010).

Perilaku konsumsi alkohol juga sering ditemukan di Kecamatan Gringsing Kabupaten Batang. Menurut Badan Narkotika Nasional (BNN) Gringsing, perilaku konsumsi alkohol pada remaja tidak terdata karena fokus dari BNN adalah penjaringan penjual alkohol, tetapi dari data penjual alkohol sangat mudah ditemukan dan terjangkau oleh kalangan remaja, sehingga tidak menutup kemungkinan 
prosentase peminum alkohol dari kalangan remaja juga sangat tinggi. Polsek Gringsing mengatakan sering setiap penjaringanperilaku menyimpang remaja, selalu terjaring puluhan remaja sedang berpesta minuman alkohol. Remaja umumnya dari Desa Gringsing.

Perilaku konsumsi alkohol menyebabkan masalah-masalah yang sangat berbahaya meliputi ketergantungan, penyakit, kecacatan dan kematian. Data World Health Organization (WHO) melaporkan jumlah kematian di dunia akibat minuman alkohol yaitu pada tahun 2009 tercatat 775.000 penduduk dunia $(5,3 \%)$ meninggal akibat alkohol. Data tahun 2011 tercatat 2,5 juta penduduk dunia $(9 \%)$ usia muda (15-29 tahun) meninggal akibat alkohol. Data tahun 2014 tercatat 3,3 juta orang di seluruh dunia setiap tahun meninggal akibat alkohol dan dinyatakan setara dengan satu kematian setiap 10 detik (WHO, 2014).

Perilaku konsumsi minuman alkohol terjadi pada remaja usia sekitar 15-25 tahun, dengan berbagai macam faktor pendorongnya dimulai dari coba-coba, karena solidaritas terhadap teman, sebagai pencarian identitas diri ataupun sebagai pelarian diri dari masalah yang dihadapi dan juga minimnya peran orang tua untuk mengontrol anak(Kartono, 2011). Peran dan fungsi orang tua sangat penting untuk mencapai hubungan yang kuat antara anggota keluarga sebagai bentuk saling ketergantungan satu sama lain (Efendi, 2009).

Peran orang tua merupakan salah satu aspek yang penting agar remaja dapat mengatasi masalah atau stres. Kelekatan yang akrab dan positif dengan anak, kontrol pemenuhan kebutuhan anak, strategi pengasuhan yang berpusat pada anak secara konsisten dapat meredam stress atau masalah yang di hadapi remaja (Santock, 2013).Orang tua merupakan lingkungan pertama yang berhubungan dengan remaja.Orang tua harus memberikan pengertian melalui cara-cara yang dewasa, memberikan dukungan atau motivasi yang positif agar menunjang keberhasilan studi maupun nilai keakhlakan anak.Peran orang tua yang baikakan menjadikan suasana aman sehingga remaja merasa dirinya damai bila berada di tengah keluarga tersebut (Soekanto, 2014).

Penelitian oleh Puspitasari (2013) menghasilkan bahwa faktor keluarga mempunyai hubungan yang signifikan dengan perilaku antisosial pada remaja $(p=0,007)$, dimana semakin tinggi peran keluarga maka semakin rendah perilaku antisosial pada remaja dan sebaliknya. Perilaku antisosial adalah gangguan kepribadian anak yang cenderung melanggar peraturan, norma-norma sosial dan hukum yang sering muncul pada usia 15 tahun ke atas. Perilaku antisosial ini juga termasuk didalamnya adalah perilaku konsumsi minuman alkohol (Pieter \& Lubis, 2010).

Kepedulian orang tua dapat membuat remaja mampu mengontrol emosi karena keluarga menjadi tempat remaja mengeluarkan segala keluhan ataupun sekedar bercerita kegiatan sehari-hari.Seperti pada penelitian yang dilakukan oleh Suseno (2014) yang menjelaskan bahwa perhatian dan kontrol orang tua terhadap pergaulan remaja dengan terman sebayanya merupakan faktor penting terjadinya perilaku mengkonsumsi minuman alkohol di kalangan remaja.Individu dengan konsep diri yang baik dimungkinkan dapat mengendalikan emosi dengan baik sehingga tercapainya kestabilan emosi.Hasil penelitian Kalara (2014) juga menyebutkan faktor pendorong remaja mengkonsumsi alkohol adalah faktor lingkungan keluarga, lingkungan pergaulan, dan lingkungan masyarakat.

Studi pendahuluan dengan tokoh-tokoh masyarakat pada tanggal 6 Oktober 2016, mereka mengatakan bahwa perilaku konsumsi minuman alkohol di Desa Gringsing Kecamatan Gringsing Kabupaten Batang, cukup sering ditemukan.Remaja mengkonsumsi minuman alkohol biasanya secara bergerombol, pada saat acara hajatan (pernikahan) teman sebayanya, saat remaja yang sudah bekerja menerima gajian atau mereka yang telah pulang dari rantauan.Mereka minum di tempat tertutup maupun terbuka, di warung, di rumah, bahkan berani di pinggir jalan.

Dari hasil wawancara pada tanggal 6 Oktober 2016 dengan 8 orang tua yang memiliki remaja berperilaku pernah mengkonsumsi minuman alkohol didapatkan data, 2 orang tua mengatakan tidak peduli dengan anaknya karena memang anak tersebut "bandel" (nakal), dan kalau dimarahi malah "mengamuk" (kembali memarahi orang tua). Adapula 4 orang tua yang mengatakan tidak tahu apakah anaknya pemabuk atau tidak 
karena tidak tahu pergaulan anaknya diluar lingkungan rumah dimana saja. Ada pula 2 orang tua yang mengatakan anaknya bebas berperilaku apa saja termasuk merokok ataupun minum alkohol karena sudah dewasa asalkan bisa kontrol dan tidak memperkosa atau membunuh orang lain. Tujuan penelitian ini adalah untuk mengetahui hubungan peran orang tua dengan perilaku konsumsi minuman alkohol pada remaja laki-laki di Desa Gringsing Kecamatan Gringsing Kabupaten Batang.

\section{METODE}

Jenis penelitian yang digunakan dalam penelitian ini adalah deskriptif korelatif dengan pendekatan cross sectional. Populasi dalam penelitian ini adalah seluruh remaja laki-laki di Desa Gringsing Kecamatan Gringsing
Kabupaten Batang.Sesuai hasil studi pendahuluan didapatkan data seluruh remaja laki-laki yang berusia 15 - 20 tahun sebanyak 213remajaSampel penelitian sebanyak 150 orang. Teknik sampling dalam penelitian ini adalah menggunakan purposive sampling.

Alat penelitian ini menggunakan kuesioner peran orang tua terhadap perilaku minumminuman alkohol pada remajadan kuesioner perilaku remaja dalam mengkonsumsi minuman keras.Analisa menggunakan dua analisa yaitu univariat dan bivariat. Analisa bivariat menggunakan uji Chi Square Test dengan fisher exact test.

\section{HASIL}

Hasil penelitian dapat dilihat pada tabel berikut.

Tabel 1

Distribusi Frekuensi Peran orang tua $(n=150)$

\begin{tabular}{lcc}
\hline Peran Orang tua & f & $\%$ \\
\hline Kurang & 3 & 2,0 \\
\hline Cukup & 95 & 63,3 \\
\hline Baik & 52 & 34,7 \\
\hline
\end{tabular}

Tabel 1 menunjukkan peran orang tua di Desa

Gringsing mayoritas cukup dengan presentase yaitu sebanyak $95(63,3 \%)$ responden.

Tabel 2.

Distribusi Frekuensi Perilaku Konsumsi Minuman Alkohol ( $\mathrm{n}=150)$

\begin{tabular}{lrr}
\hline \multicolumn{1}{c}{ Perilaku Konsumsi Minuman Alkohol } & Frekuensi & Persentase \\
\hline Peminum Berbahaya & 84 & 56,0 \\
Peminum Tidak Berbahaya & 36 & 24,0 \\
Bukan Peminum Alkohol & 30 & 20,0
\end{tabular}

Tabel 2 menunjukkan perilaku Konsumsi Minuman Alkohol pada Remaja Laki-laki di Desa Gringsing sebanyak 84 (56,0\%)remaja peminum berbahaya.Sehingga dapat disimpulkan bahwa remaja di Desa Gringsing sebagian besar berperilaku peminum berbahaya.

Tabel 3

Peran Orang tua dengan Perilaku Konsumsi Minuman Alkohol $(\mathrm{n}=150)$ Perilaku Konsumsi Minuman

Alkohol

\begin{tabular}{|c|c|c|c|c|c|c|c|c|}
\hline \multirow{3}{*}{ Peran Orang Tua } & & \multirow{2}{*}{\multicolumn{2}{|c|}{ Total }} & \multirow{3}{*}{ OR $(95 \% \mathrm{CI})$} & \multirow{3}{*}{$\begin{array}{c}p \\
\text { value }\end{array}$} \\
\hline & \multicolumn{2}{|c|}{$\begin{array}{l}\text { Peminum } \\
\text { Alkohol }\end{array}$} & \multicolumn{2}{|c|}{$\begin{array}{l}\text { Bukan } \\
\text { peminum } \\
\text { alkohol }\end{array}$} & & & & \\
\hline & $\mathrm{f}$ & $\%$ & $\mathrm{f}$ & $\%$ & $\mathrm{f}$ & $\%$ & & \\
\hline Cukup dan Kurang & 77 & 51,3 & 21 & 14,0 & 98 & 65,3 & 0,767 & 0,669 \\
\hline Baik & 43 & 28,7 & 9. & 6,0 & 52 & 34,7 & $\begin{array}{c}\text { (95\% CI: } 0,323- \\
1,823)\end{array}$ & \\
\hline
\end{tabular}


Berdasarkan hasil analisis hubungan antara peran orang tua dengan perilaku konsumsi minuman alkohol pada remaja diperoleh bahwa sebanyak $77(51,3 \%)$ remaja sebagai peminum beralkohol dengan peran orang tua yang cukup dan kurang, sebanyak $43(28,7)$ remaja sebagai peminum alkohol dengan peran orang tua yang baik sedangkan remaja yang bukan peminum beralkohol memiliki peran orang tua cukup dan kurang sebanyak 21 $(14,0 \%)$ remaja dan remaja bukan peminum beralkohol tetapi peran orang tua baik sebanyak $9(6,0 \%)$ remaja. Hasil uji statistik didapatkan $\mathrm{p}$ value $=0,669$ maka dapat disimpulkan bahwa tidak terdapat hubungan antara peran orang tua dengan perilaku konsumsi minuman alkohol para remaja lakilaki. Hasil penelitian didapatkan nilai OR sebesar 0,767 dengan batas bawah 0,323 dan batas atas 1,823 pada interval confidence $95 \%$. Dari hasil statistik tersebut menunjukkan bahwa OR < 1 yaitu 0,767 yang artinya peran orang tua cukup dan kurang berpeluang sebesar 0,767 kali terjadinya perilaku konsumsi minumal alkohol pada remaja dibandingkan peran orang tua baik.

\section{PEMBAHASAN}

\section{A. Peran Orang Tua}

Hasil penelitian menunjukkan bahwa sebagian besar peran orang tua cukup sebanyak 95 responden (63,3\%). Hal ini menunjukkan bahwa peran orang tua sudah cukup dalam memberikan motivator, edukator dan fasilitator kepada remaja untuk tidak mengkonsumsi minuman beralkohol.

Peran orang tua cukup dalam memberikan motivator dapat dilihat dari pernyataan responden yang menyatakan bahwa orang tua kadang-kadang menanyakan kemana akan pergi, mencemaskan ketika pergi keluar rumah, kadang-kadang mau mendengarkan keluhan, memperdulikan ketika sedang mengalami suatu masalah, sering melarang untuk melakukan hal-hal yang melanggar aturan hukum keluarga dan sosial, selalu memberikan pujian atas prestasi yang saya raih, kadang-kadang memberikan informasi bahayanya minum-minuman alkohol dan selalu perhatian terutama dalam hal pergaulan dan menjelaskan dampak dari pergaulan yang salah.

Sesuai dengan teori bahwa peran orang tua merupakan salah satu aspek yang penting agar remaja dapat mengatasi masalah atau stres (Santock, 2013).Orang tua harus memberikan pengertian melalui cara-cara yang dewasa, memberikan dukungan atau motivasi yang positif untuk menunjang keberhasilan akhlak remaja (Soekanto, 2014).

Orang tua sebagai motivator adalah orang yang memberikan motivasi atau mendorong anggota keluarganya untuk bertindak.Secara klinis, motivasi diperlukan untuk mendapatkan kekuatan pada pasien yang mendapat perawatan. Motivasi didasari atas suatu kebutuhan, tujuan dan tingkah laku yang khas, sehingga adanya motivasi dan dorongan dari orang tua kepada remaja akan menimbulkan kehangatan dalam keluarga dan remaja terhindar dari perilaku menyimpang seperti konsumsi minuman alkohol (Effendi, 2009). Remaja yang kurang mendapatkan perhatian, kasih sayang dan tuntunan orang tua, serta motivasi dari orang tua, karena ayah dan ibunya masing-masing sibuk mengurusi permasalahan serta konflik batin sendiri menyebabkan anak melakukan tindakantindakan menyimpang, dan pada masa remaja cenderung labil sehingga mudah melakukan perilaku menyimpang seperti konsumsi minuman alkohol (Kartono, 2011: Santrock, 2013).

Dilihat dari indikator edukator, responden menyatakan orang tuanya kadang-kadang memberikan informasi tentang penyalahgunaan alcohol, mengajari cara memilih teman dan bergaul, memberikan arahan dalam memilih cita-cita, memberikan informasi tentang aturan-aturan dalam berprilaku yang baik dalam aturan agama dan sosial.

Sesuai dengan teori yang menyatakan bahwa orang tua wajib memberikan pendidikan kesehatan kepada anggota keluarganya dalam menanamkan perilaku sehat, sehingga terjadi perubahan perilaku seperti yang diharapkan dalam mencapai tingkat kesehatan yang optimal (Effendi, 2009). Peran orang tua sebagai edukator dapat dilakukan dengan cara mengajarkan anak menghindari perilaku negatif, mengajarkan penolakan terhadap perilaku negatif, mengajarkan dampak perilaku negatif, dan mengajarkan memperdulikan kesehatan (Kartono, 2011). 
Dilihat dari indikator fasilitator responden menyatakan orang tuanya kadang-kadang mengawasi dalam bergaul, membantu memberikan solusi ketika bingung dalam mengambil keputusan, memfasilitasi hobi yang bersifat positif. Orang tua kadang-kadang juga menanyakan keinginan atau cita-cita.Orang tua juga mencukupi kebutuhan sehari-hari seperti makan, pakaian, sepatu dan memberikan uang saku.

Sesuai dengan teori bahwa orang tua sebagai fasilitator adalah menanamkan perilakuperilaku menyimpang pada anggota keluarga, maka selayaknya kepala keluarga menggunakan segala upaya untuk menyediakan sarana prasarana terkait dengan perilaku hidup bersih dan sehat (Setiadi, 2008). Peran orang tua sebagai fasilitator dapat dilakukan dengan memberi dukungan jasmani seperti pelayanan, bantuan finansial dan material berupa bantuan nyata dengan bantuan langsung, seperti saat seseorang memberi atau meminjamkan barang atau uang, menyediakan transportasi, menjaga dan merawat saat sakit ataupun saat mengalami depresi yang dapat membantu memecahkan atau menyelesaikan masalah (Friedman, 2010).

Hasil penelitian terdapat peran orang tua kurang sebanyak 3 responden $(2,0 \%)$. Hal ini terjadi karena orang tua kurang memberikan dalam hal motivasi, edukasi dan kurang memberikan fasilitas.Hal ini bisa saja terjadi karena beberapa faktor, seperti faktor sosial meliputi meliputi sosial ekonomi, jenis pekerjaan, sarana dan prasarana sosial, pendidikan, dan penghasilan.Faktor pengetahuan meliputi pengetahuan orang tua kurang tentang perilaku sehat.Sikap negative dari orang tua.Faktor lainnya seperti faktor peristiwa situasional masalah kesehatan atau sakit, dan faktor keturunan.Sesuai dengan teori menurut Notoatmodjo (2012), ada beberapa faktor yang mempengaruhi peran orang tua di dalam keluarganya sendiri yaitu seperti faktor sosial, pengetahuan, sikap, faktor peristiwa situasional masalah kesehatan atau sakit, dan faktor keturunan.

Hasil penelitian sesuai dengan penelitian yang dilakukan oleh Puspitasari (2013) menghasilkan bahwa faktor keluarga mempunyai hubungan yang signifikan dengan perilaku antisosial pada remaja $(\mathrm{p}=0,007)$, dimana semakin tinggi peran keluarga maka semakin rendah perilaku antisosial pada remaja dan sebaliknya. Hasil penelitian yang dilakukan oleh Prayugo (2014) yang menyatakan bahwa sebagian besar pola asuh orang tua dapat mejadi salah satu penyebab remaja mengkonsumsi minuman beralkohol kategori cukup.Penelitian yang dilakukan oleh Herdajani (2013) yang menyatakan bahwa peran orang tua dalam upaya penanggulangan penyalahgunaan narkoba ini sangat berpengaruh, karena orang tua adalah orang yang paling dekat. Berbeda dengan penelitian yang dilakukan oleh Afirosidah (2015) menyatakan bahwa peran orang tua dalam pencegahan konsumsi minuman beralkohol sebagian besar 37 responden atau (54.4\%) berperan buruk, dan hampir setengahnya 31 responden atau $(45.6 \%)$ berperan baik.

\section{B. Perilaku Konsumsi Minuman Alkohol}

Hasil penelitian menunjukkan bahwa sebagian besar perilaku konsumsi minuman beralkohol peminum berbahaya sebanyak 84 responden $(56,0 \%)$, peminum tidak berbahaya sebanyak 36 responden $(24,0 \%)$ dan bukan peminum sebanyak 30 responden $(20,0 \%)$. Hal ini menunjukkan bahwa sebagian besar responden peminum alkohol yang berbahaya.

Perilaku konsumsi minuman beralkohol kategori peminum berbahaya jika dikonsumsi secara berlebihan dan terus menerus lebih dari $4 \mathrm{x}$ dalam seminggu, lebih dari 10 minuman yang diminum pada hari-hari biasa, hampir setiap hari minum alkohol sampai lebih dari 8 minuman di tahun lalu. Setahun terakhir menyadari merasa tidak dapat berhenti minum alkohol, sering mengalami kegagalan hampir setiap hari dikarenakan kebiasaan minum alkohol, sering merasa membutuhkan minuman beralkohol di pagi hari untuk menyemangati, sering merasa tidak menyesal setelah minum, sering tidak dapat mengingat setelah minum, pernah terluka atau melukai orang lain akibat kebiasaan minum alkohol, pernah kerabat, teman, dokter atau petugas kesehatan lain menyarankan untuk mengurangi perilaku minum alkohol (Nurwijaya \& Zullies, 2009).

Perilaku konsumsi minuman beralkohol peminum tidak berbahaya jika dikonsumsi tidak berlebihan misalnya sekali dalam sebulan, minuman yang diminum 1 sampai 3 minuman, setahun terakhir menyadari merasa dapat berhenti minum alkohol, mengkonsumsi minuman beralkohol tidak sampai setiap bulan dan sering merasa menyesal setelah minum 
dan belum pernah terluka atau melukai orang lain akibat minum alkohol. Sedangkan perilaku bukan peminuman beralkohol yaitu seseorang yang belum pernah mengkonsumsi minuman yang mengandung alkohol(Nurwijaya \& Zullies, 2009).

Pemakaian alkohol di Indonesia menunjukkan potensi peningkatan penggunaan alkohol yang cukup besar. Berdasarkan data Riset Kesehatan Dasar (Riskesdas) tahun 2007, prevalensi konsumsi alkohol di Indonesia dari 258.366 sampel rumah tangga pada 1 tahun terakhir adalah $8,8 \%$ laki-laki dan $0,7 \%$ perempuan. Prevalensi peminum alkohol mulai tinggi pada umur antara 15-24 tahun yaitu sebesar 5,5\% meningkat menjadi $6,7 \%$ pada umur $25-34$ tahun (Kemenkes. RI, 2007).

Hasil penelitian menunjukkan bahwa sebagian besar perilaku konsumsi minuman beralkohol peminum berbahaya.Hal ini ditunjukkan dengan pernyataan responden yang menyatakan sering minum minuman yang mengandung alkohol 7 sampai 9 minuman hampir setiap hari.Serupa dengan hasil penelitian yang dilakukan oleh Prayugo (2014) tentang "Hubungan Pola Asuh Orang Tua Dengan Perilaku Mengkonsumsi Minuman Beralkohol Pada Remaja Di Desa Wonojati Kecamatan Jenggawah Kabupaten Jember". Hasil penelitiannya didapatkan hasil bahwa sebagian besar remaja di Desa Wonojati Kecamatan Jenggawah Kabupaten Jember berperilaku mengkonsumsi minuman beralkohol. Penelitian lain yang dilakukan oleh Issakh (2012) yang meneliti tentang "Gambaran Perilaku Remaja Terhadap Kebiasaan Mengonsumsi Minuman Beralkohol Di Desa Sapa Kecamatan Tenga Kabupaten Minahasa Selatan" juga menyatakan bahwa remaja yang mengkonsumsi alkohol sebanyak $(76,3 \%)$ remaja lebih besar daripada yang tidak mengkonsumsi minuman beralkohol $(23,7 \%)$ remaja.

Sesuai dengan teori bahwa perilaku mengkonsumsi minuman alkohol merupakan tindakan atau aktivitas dari remaja mengkonsumsi minuman yang mengandung alkohol (Notoatmodjo, 2012).Perilaku tersebut merupakan perilaku menyimpang yang melanggar aturan dan status, perilaku yang membahayakan diri sendiri dan orang lain, perilaku yang mengakibatkan korban materi, dan perilaku yang mengakibatkan korban fisik (Kartono, 2011; Hurlock, 2010).

Menurut Kartono (2011) bahwa faktor yang mempengaruhi terjadinya perilaku menyimpang remaja yaitu: anak kurang mendapatkan perhatian, kasih sayang dan tuntunan orang tua, terutama bimbingan ayah, kebutuhan fisik maupun psikis anak-anak remaja menjadi tidak terpenuhi, anak tidak pernah mendapatkan latihan fisik dan mental yang sangat diperlukan untuk hidup normal.

Joewana (2008) menambahkan bahwa penyebab seseorang menjadi pecandu alkohol belum diketahui secara pasti, namun penggunaan alkohol bukan satu-satu nya faktor penyebab.Dari orang-orang yang mengonsumsi alkohol, sekitar $10 \%$ nya menjadi pecandu. Beberapa alasan individu mengonsumsi alkohol antara lain adalah agar berani mengambil resiko, menenangan diri, mengatasi diri, lari dari rasa sepi, melupakan kesedihan, merasa percaya diri, mengatasi depresi, menyesuaikan diri untuk situasi sosial, menghilangkan rasa sakit, mengatasi stress pribadi.

Hasil penelitian terdapat $(24,0 \%)$ responden yang peminum alkohol tidak berbahaya. Hal ini terjadi karena responden menyatakan minum minuman yang mengandung alkohol 24x dalam sebulan, 1 sampai 3 minuman, minum alkohol tidak sampai setiap bulan dalam setahun terakhir.

Sesuai dengan teori bahwa Perilaku konsumsi minuman beralkohol peminum tidak berbahaya jika dikonsumsi tidak berlebihan misalnya sekali dalam sebulan, minuman yang diminum 1 sampai 3 minuman, setahun terakhir menyadari merasa dapat berhenti minum alkohol, mengkonsumsi minuman beralkohol tidak sampai setiap bulan dan sering merasa menyesal setelah minum dan belum pernah terluka atau melukai orang lain akibat minum alkohol(Nurwijaya \& Zullies, 2009).

Menurut Kartono (2011), seorang remaja berperilaku mengkonsumsi minuman alkohol dipengaruhi oleh faktor internal dan faktor eksternal. Faktor internal individu meliputi : faktor kepribadian, pengaruh usia, pandangan atau keyakinan yang keliru, religius yang rendah dan ego yang tidak realistis. Faktor eksternal individu dan faktor lingkungan 
meliputi: faktor keluarga, lingkungan tempat tinggal, teman sebaya, keadaan sekolah dan pendidikan.

Hasil penelitian terdapat $(20,0 \%)$ responden yang bukan peminum, hal ini ditunjukkan dengan pernyataan responden yang menyatakan tidak pernah minum-minuman beralkohol. Remaja tidak minum-minuman beralkohol karena adanya kesadaran responden akan bahaya minum-minuman keras. Remaja menyadari bahaya dan dampak negatif dari minum-minuman berbahaya yang meliputi ketergantungan, penyakit, kecacatan dan kematian. Faktor keluarga terutama peran orang tua untuk mengontrol anak untuk tidak minum-minuman beralkohol.Lingkungan tempat tinggal yang terbebas dari minumminuman beralkohol.Teman sebaya yang sebagian besar tidak terpengaruh perilaku minum-minuman beralkohol.Keadaan sekolah dan pendidikan yang mengajarkan bahaya minum-minuman kelas, dan faktor religius yang tinggi dari responden.

Hasil penelitian berbeda dengan peneiltian yang dilakukan oleh Desi Maria Ulfah, (2005) yang menyatakan bahwa minum-minuman keras terhadap kalangan remaja di desa Losari minum-minuman keras umumnya disebabkan faktor-faktor yang melatar belakangi di antaranya, faktor rasa ingin tahu, pelarian dari masalah yang dihadapi, mudahnya remaja mendapatkan minuman keras, faktor ekonomi, faktor pendidikan agama.

\section{Hubungan Peran Orang Tua Dengan Perilaku Konsumsi Minuman Alkohol}

Hasil penelitian menunjukkan bahwa tidak ada hubungan antara peran orang tua dengan perilaku konsumsi minuman alkohol. Peran orang tua baik sebagian besar perilaku remaja peminum berbahaya, peran orang tua cukup sebagian besar perilaku remaja peminum berbahaya, begitupula peran orang tua kurang sebagian besar perilaku remaja juga peminum berbahaya. Hal ini menunjukkan bahwa apapun peran orang tua maka perilaku remaja tetap banyak yang mengkonsumsi minuman alkohol.

Sesuai dengan teori faktor-faktor yang menyebabkan remaja mengkonsumsi alkohol adalah faktor internal dan faktor eksternal remaja. Faktor internal meliputi faktor kepribadian, usia remaja, pandangan dan keyakinan yang keliru, religius yang rendah dan ego yang tidak realistis. Sedangkan faktor eksternal meliputi faktor keluarga, lingkungan tempat tinggal, teman sebaya, keadaan sekolah dan pendidikan (Kartono (2011). Sehingga dimungkinkan penyebab remaja di desa Gringsing Kabupaten Batang mengkonsumsi alkohol adalah karena peran orang tua dan dan faktor-faktor lain.

Menurut penelitian lain penelitian yang berkaitan dengan perilaku mengkonsumsi minuman beralkohol pada remaja, hasil penelitian berbeda dengan penelitian yang dilakukan oleh Prayugo (2014) yang meneliti tentang "Hubungan Pola Asuh Orang Tua Dengan Perilaku Mengkonsumsi Minuman Beralkohol Pada Remaja Di Desa Wonojati Kecamatan Jenggawah Kabupaten Jember". Hasil penelitiannya menyatakan ada hubungan yang bermakna antara pola asuh orang tua dengan perilaku mengkonsumsi minuman beralkohol pada remaja di Desa Wonojati Kecamatan Jenggawah Kabupaten Jember ( $p$ value: 0,035, $\alpha: 0,05$ ).

\section{SIMPULAN DAN SARAN \\ Simpulan}

Berdasarkan hasil penelitian dapat disimpulkan bahwa:

1. Peran orang tua pada remaja laki-laki di Desa Gringsing Kecamatan Gringsing Kabupaten Batang sebagian besar cukup yaitu sebanyak 95 responden $(63,3 \%)$.

2. Perilaku konsumsi minuman alkohol pada remaja laki-laki di Desa Gringsing Kecamatan Gringsing Kabupaten Batang sebagian besar peminum berbahaya yaitu sebanyak 84 responden $(56,0 \%)$.

3. Tidak ada hubungan peran orang tua dengan perilaku konsumsi minuman alkohol pada remaja laki-laki di Desa Gringsing Kecamatan Gringsing Kabupaten Batang dengan $\mathrm{p}$ value 0,669

\section{Saran}

\section{Bagi orang tua}

Mengingat masih terdapat $(2,0 \%)$ peran orang tua yang kategori kurang, maka diharapkan orang tua untuk berperan aktif sebagai motivator, edukator dan fasilitator agar remaja tidak berperilaku mengkonsumsi minum-minuman keras. Orang tua harus memotivasi remaja untuk tidak mengkonsumsi minum-minuman keras, memberikan pengetahuan tentang bahaya minuman keras kepada remaja bertindak tegas untuk melarang anaknya minum-minuman keras 
dan tidak memberikan fasilitas kepada anak untuk minum-minuman keras.

\section{Bagi Remaja}

Diharapkan bagi remaja untuk mengurangi konsumsi minuman keras dari segi frekuensi, lamanya berlangsung dan intensitas, berfikir positif saat mengalami sebuah permasalahan, banyak mencari informasi atau membaca buku tentang akibat-akibat yang disebabkan jika mengkonsumsi minuman keras terlalu banyak dan lebih berhati-hati dalam mencari teman.

3. Intitusi keperawatan (STIKES Kendal)

Hasil penelitian ini disarankan dapat digunakan untuk referensi bagi mahasiswa yang akan menyusun skripsi terutama tentang "Hubungan Peran Orang tua dengan Perilaku Konsumsi Minuman Alkohol pada Remaja Laki-Laki di Desa Gringsing Kecamatan Gringsing Kabupaten Batang".

4. Bagi peneliti Selanjutnya

Diharapkan bagi peneliti lain untuk memperhatikan faktor-faktor lain yang dapat mempengaruhi seperti faktor intern (kepribadian, usia, pandangan/keyakinan, religius, ego yang tidak realistis) dan ekstern (keluarga, lingkungan tempat tinggal, teman sebaya, sekolah dan pendidikan)

\section{DAFTAR PUSTAKA}

Afirosidah.I. (2015).Peran Orang Tua Dalam Pencegahan Konsumsi Minuman Beralkohol pada Remaja.Karya Tulis Ilmiah. Universitas Muhammadiyah Ponorogo

Desi Maria Ulfah, (2005). Faktor-Faktor Penggunaan Minuman Keras di Kalangan Remaja di Desa Losari Kecamatan Rembang Kabupaten Purbalingga.Skripsi. Universitas Negeri Semarang

Dinkes Propinsi Jateng, (2010). Profil kesehatan povinsi Jawa Tengah. Dinas Kesehatan. Pemerintah Provinsi Jawa Tengah

Efendi, Ferry \& Makhfudli. (2009) . Keperawatan Kesehatan Komunitas :Teori dan praktek dalam Keperawatan. Jakarta : Salemba Medika.
Friedman, M.M. (2010). Keperawatan Keluarga : teori dan praktek edisi 3. Jakarta : EGC.

Hurlock, E.B. (2010). Psikologi Perkembangan Edisi kelima. Jakarta: Erlangga.

Herdajani (2013). Peran Orangtua Dalam Mencegah Dan Menanggulangi Penggunaan Zat Adiktif Dan Psikotropika Pada Remaja (Sebuah Tinjauan Psikologis). Prosiding Seminar Nasional Parenting 2013.

Hutagalung. (2008). Gangguan Penggunaan Zat Narkotika, Alkohol, dan Zat Adiktif Lainnya.Jakarta : Gramedia.

Issakh, R. A. (2012). Gambaran Perilaku Remaja Terhadap Kebiasaan Mengonsumsi Minuman Beralkohol Di Desa Sapa Kecamatan Tenga Kabupaten Minahasa Selatan. Jurnal e-Biomedik $(\mathrm{eBm})$, Volume 4, Nomor 1, JanuariJuni 2016

Joewana, S. (2008). Gangguan Penggunaan Zat Narkotika, Alkohol, dan Zat Adiktif Lainnya. Jakarta : Gramedia.

Kalara.(2014). Gambaran Perilaku Konsumsi Alkohol pada Mahasiswa.Jurnal STIKES Ngudi Waluyo.

Kartono. (2011). Perilaku Manusia. Jakarta: ISBN

Kemenkes RI. (2012). Survei Demografi danKesehatan Indonesia2012: KesehatanReproduksi Remaja. Badan Pusat Statistik Kependudukan dan Keluarga Berencana Nasional Indonesia

Kemenkes, RI, (2007). Riskesdas Laporan Nasional 2007:Perilaku Minum Minuman Beralkohol. Badan Penelitian dan Pengembangan Kesehatan.

Kiswoyo, Eddy., dkk. (2013). Ayo Menjadi Remaja Berkarakter : Religius, Sehat, Cerdas, Produktif.Jakarta : Direktorat Kerjasama Pendidikan Kependudukan BKKBN, 2013.2 From: http://www.bkkbn.go.id/ publikasi.pdf. diunduh tanggal 22 Desember 2016 
Kumara.(2016). Konsumen Alkohol Terbesar di Dunia. http://databoks.katadata.co.id/datapublis h/2016/09/28/konsumen-alkohol-perkapita-terbesar-di-dunia diunduh tanggal 22 Desember 2016

Notoatmodjo, S. (2012).Promosi Kesehatan \& Ilmu Perilaku.Jakarta : Rineka Cipta.

Nurwijaya, H \& Zullies, I. (2009).Bahaya Alkohol dan Cara Mencegah Kecanduannya. Jakarta: PT Elex Media Komputido.

Pieter, H.Z\& Lubis, N.L. (2010).Pengantar Psikologi dalam Keperawatan. Jakarta: Kencana.

Prayugo (2014). Hubungan Pola Asuh Orang Tua Dengan Perilaku Mengkonsumsi Minuman Beralkohol Pada Remaja Di Desa Wonojati Kecamatan Jenggawah Kabupaten Jember. Skripsi. Universitas Jember

Puspitasari.(2013). Hubungan Dukungan Keluarga dan Interaksi Teman Sebaya dengan Perilaku Antisosial pada Remaja di SMA Gita Bahari Semarang.Skripsi Unniversitas Muhammadiyah Semarang.
Santrock, J.W. (2013). Remaja (Jilid 2) (Edisi 11). Jakarta : Erlangga.

Setiadi. (2008). Konsep Dasar keperawatan Keluarga. Jakarta: Salemba Medika.

Soekanto. (2014). Sosiologi Suatu Pengantar. Jakarta : PT Raja Grafindo Persada.

Stanhope, M., \& Lancaster, J. (2014). Community and Public Health Nursing. St Louis Missouri: Mosby.

Suseno (2014).Perilaku Mengkonsumsi Minuman Keras Di Kalangan Remaja Awal Di Desa Kunden Kecamatan Wirosari Kabupaten Grobogan Tahun 2014. Jurnal Kesehatan Universitas Dian Nuswantoro

WHO.(2014). Global status report on alcohol and health - 2014.ISBN 978924 069276 3.WHO Library Cataloguing-inPublication Data.from: http://www.who.int/substance abuse/pu blications/global alcohol report/en/ diakses 15 Desember 2016 